Volume 1 Nomor 2 Edisi Desember 2013
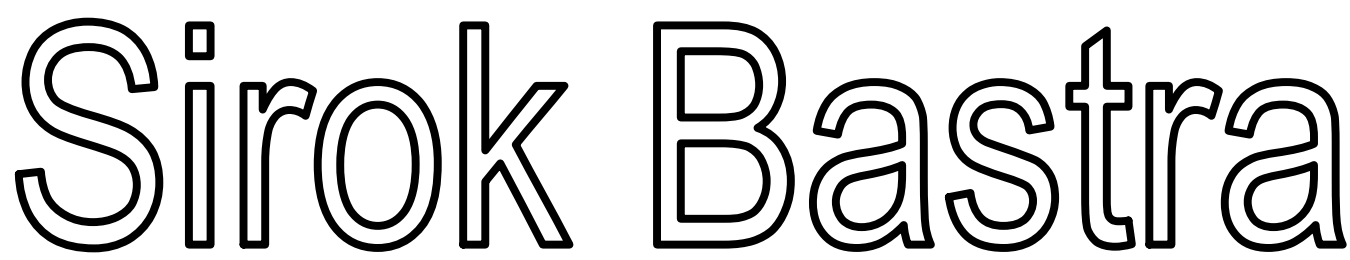

J URNAL ILMIAH KEBAHASAAN DAN KESASTRAAN

\begin{tabular}{|c|c|c|c|c|c|}
\hline $\begin{array}{c}\text { Sirok Bastra } \\
\text { Jurnal Kebahasaan dan } \\
\text { Kesastraan }\end{array}$ & Volume 1 & Nomor 2 & $\begin{array}{c}\text { Hlm. } \\
123-249\end{array}$ & $\begin{array}{c}\text { Pangkalpinang, } \\
\text { Desember } \\
2013\end{array}$ & $\begin{array}{c}\text { ISSN } \\
2354-7200\end{array}$ \\
\hline
\end{tabular}

KANTOR BAHASA KEPULAUAN BANGKA BELITUNG 

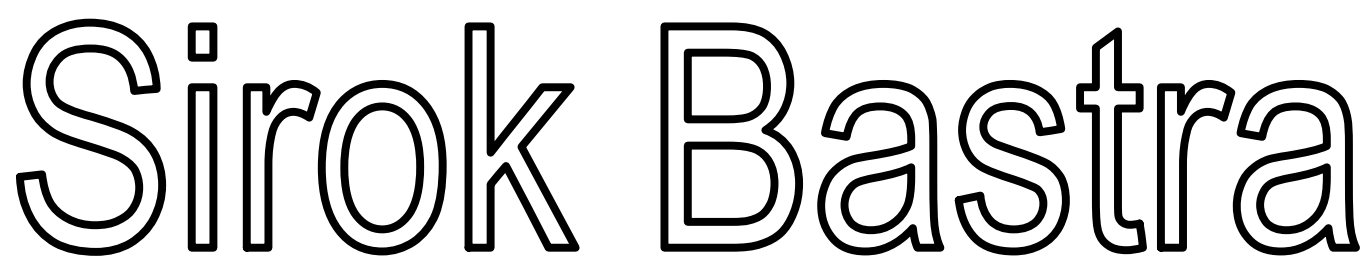

\section{J URNAL ILMIAH KEBAHASAAN DAN KESASTRAAN}

Jurnal ini merupakan wadah informasi mengenai kebahasan, kesastraan, dan pengajarannya yang memuat hasil penelitian, studi kepustakaan, dan tulisan ilmiah bidang kebahasan, kesastraan, dan pengajarannya. Jurnal ini terbit dua kali setahun, yakni Juni dan Desember, serta terbit sejak Juni 2013.

\section{Penanggung Jawab}

Kepala Kantor Bahasa Provinsi Bangka Belitung

Drs. Umar Solikhan, M.Hum.

\section{Mitra Bestari}

Prof. Dr. Agus Nuryatin, M.Hum. (Bidang Bahasa dan Pengajarannya)

Prof. Amrin Saragih, Ph.D., M.A. (Bidang Sastra dan Pengajarannya)

Dr. Felicia Nuradi Utorodewo, M.Hum. (Bidang Bahasa dan Pengajarannya)

Dr. Pujiharto, M.Hum. (Bidang Sastra dan Pengajarannya)

\section{Pemimpin Redaksi}

Rahmat Muhidin, S.S.

\section{Penyunting}

Prima Hariyanto, S.Hum.

\section{Perancang Sampul}

Feri Pristiawan, S.S.

\section{Kesekretariatan}

Khaliffitriansyah, S.Pd. Dea Letriana Cesaria, S.Hum.

Lia Aprilina, S.Pd.

Andrian Priyatno, A.Md.

Elzam

\section{Alamat Redaksi dan Penerbit}

Kantor Bahasa Provinsi Bangka Belitung

Ruko Permata 7, Jalan Solihin G.P. Km 4, Pangkalpinang, Kep. Bangka Belitung

Telp./Faks.: 0717-438455, Pos-el: sirokbastra@gmail.com

Pemuatan suatu tulisan dalam jurnal ini tidak berarti redaksi menyetujui isi tulisan tersebut. Isi tulisan menjadi tanggung jawab penulis. Tulisan telah ditinjau oleh mitra bestari. Setiap karangan dalam jurnal ini dapat diperbanyak setelah mendapat izin tertulis dari penulis, redaksi, dan penerbit. 


\section{KATA PENGANTAR}

Puji syukur ke hadirat Pemilik dan Pencipta semesta ini yang memiliki kuasa atas diri-Nya sendiri. Dialah Tuhan Yang Maha Esa yang telah memberikan rahmat dan hidayah-Nya sehingga Volume 1 Nomor 2 Jurnal Sirok Bastra dapat terbit tepat pada waktunya.

Pada nomor kedua ini, dimuat sebelas tulisan, yakni enam tulisan kebahasaan, empat kesastraan, dan satu pengajaran sastra. Dari segi bahasa, sebagian besar tulisan disajikan dalam bahasa Indonesia, hanya dua tulisan yang disajikan dalam bahasa Inggris. Kami mengucapkan terima kasih kepada para penulis yang telah bersedia menerbitkan karya mereka pada edisi ini. Para penulis merupakan para peneliti, pakar, dosen, dan mahasiswa dari berbagai perguruan tinggi dan instansi. Terima kasih juga kami sampaikan kepada para mitra bestari kami yang telah memberi ulasan terhadap tulisan-tulisan yang masuk ke redaksi.

Demi memenuhi keberagaman isi dan penulis, Sirok Bastra membuka kesempatan bagi para peneliti dan penulis menyampaikan hasil penelitian dan pemikiran mutakhir dalam bidang kebahasaan, kesastraan, dan pengajarannya.

Pangkalpinang, Desember 2013

Tim Redaksi 


\section{UCAPAN TERIMA KASIH UNTUK MITRA BESTARI}

Redaksi Sirok Bastra mengucapkan terima kasih kepada para mitra bestari yang telah meninjau, menimbang, dan mengulas makalah-makalah yang diterbitkan dalam Sirok Bastra Volume 1 Nomor 2, edisi Desember 2013, yakni

Prof. Dr. Agus Nuryatin, M.Hum.

Bidang Sastra dan Pengajarannya

Universitas Negeri Semarang

Semarang, Jawa Tengah

Prof. Amrin Saragih, Ph.D., M.A.

Bidang Bahasa dan Pengajarannya

Universitas Negeri Medan

Medan, Sumatra Utara

Dr. Felicia Nuradi Utorodewo, M.Hum.

Bidang Bahasa dan Pengajarannya

Universitas Indonesia

Depok, Jawa Barat

\section{Dr. Pujiharto, M.Hum.}

Bidang Sastra dan Pengajarannya

Universitas Gadjah Mada

Yogyakarta, Daerah Istimewa Yogyakarta 


\section{DAFTAR ISI}

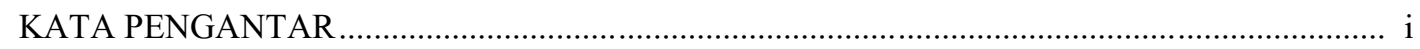

UCAPAN TERIMA KASIH UNTUK MITRA BESTARI .................................................... ii

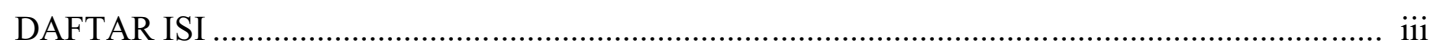

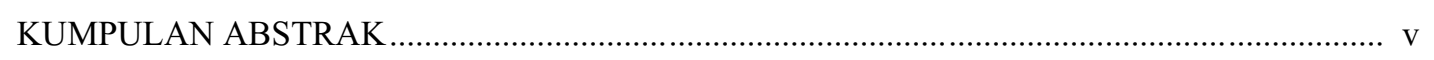

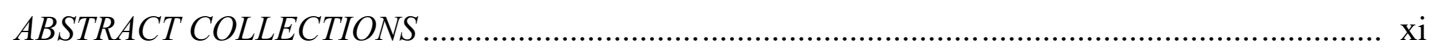

BAHASA INDONESIA DALAM INFORMASI DAN IKLAN DI RUANG PUBLIK KOTA PANGKALPINANG

(Indonesian in Information and Advertising in Public Space Pangkalpinang)

Umar Solikhan $123-129$

PERBEDAAN MAKNA NOMINA BERAFIKS $P E-, P E R-, P E--A N$, DAN $P E R--A N$ DALAM NASKAH HIKAYAT BAYAN BUDIMAN, HIKAYAT MUHAMMAD HANAFIYYAH, DAN HIKAYAT RAJA PASAI

(Affixed Noun Meaning Differences of pe-, per-, pe--an, and per--an in The Hikayat Bayan Budiman, Hikayat Muhammad Hanafiyyah, and Hikayat Raja Pasai Manuscripts)

Rindias H. Fatmasari $131-147$

WACANA RUBRIK INTIMATE DI MAJALAH DIGITAL INTERAKTIF MALE

(Intimate Rubric in Male Digital Interactive Magazine Discourse)

Prima Hariyanto $149-160$

AN ACOUSTICAL CONTRASTIVE ANALYSIS OF SUNDANESE CENTRAL VOWELS (Analisis Konstrastif Akustik Vokal Pusat Bahasa Sunda)

Yusup Irawan. $161-175$

KATA SUDAH SEBAGAI PENANDA ASPEK DENGAN AWALAN TER-

The Word of Sudah as An Aspect with Prefix Ter-

Dea Letriana Cesaria $177-182$

PERUBAHAN DAN PERGESERAN MAKNA DALAM KATA-KATA BERDERIVASI NOMINA KE VERBA YANG MENGANDUNG AFIKS $M E(N)-, M E(N)-K A N$, DAN $M E(N)-I$ PADA SURAT KABAR HARIAN KOMPAS

(Change and Shift of Meaning in The Derivated Words Nomine to Verb That Contain Affixes $m e(N)-$, me(N)-kan, dan me(N)- $i$ in The Kompas The Daily Newspaper)

Teodora Nirmala Fau $183-193$

MENCIPTA-KREATIF NASKAH DRAMA DENGAN STRATEGI MENULIS TERBIMBING (Creative Writing of Playscript eith Guided Writing Strategy)

Sony Sukmawan. $195-205$ 
PENGARUH KONSEP HAGABEON, HAMORAON, DAN HASANGAPON TERHADAP

KETIDAKSETARAAN GENDER DALAM AMANG PARSINUAN

(The Influence of Hagabeon, Hamoraon, and Hasangapon Concept for Gender Inequality in Amang Parsinuan)

Fransiska Simangunsong $207-220$

PERSPEKTIF PENGARANG MENGENAI RELASI ANTARA MANUSIA DAN

LINGKUNGAN HIDUP DALAM NOVEL PARTIKEL KARYA DEWI LESTARI: SEBUAH KAJIAN EKOKRITISISME

(Author's Perspective on The Relationship Between Humans and The Environment in The Novel Partikel Written by Dewi Lestari: an Ecocriticism Studies)

Alfi Yusrina Ramadhani $221-229$

FENOMENA HUKUM ADAT BALI TERHADAP BAYI KEMBAR BUNCING DALAM

NOVEL INCEST KARYA I WAYAN ARTIKA

Bali Custom Law Phenomenon of Kembar Buncing Infant in I Wayan Artika Novel Incest Annisa Aprinandri Irwin dan Khansa Khairunnisa $231-241$

RELIGIOUS AND MORAL VALUES IN MADURA FOLKTALES

Religiositas dan Nilai Moral dalam Cerita-Cerita Rakyat Madura

Imron Wakhid Harits. $243-249$ 


\title{
MENCIPTA-KREATIF NASKAH DRAMA DENGAN STRATEGI MENULIS TERBIMBING
}

\section{Creative Writing of Playscript eith Guided Writing Strategy}

\author{
Sony Sukmawan \\ Fakultas Ilmu Budaya, Universitas Brawijaya \\ Jalan Veteran, Malang 65145 \\ pos-el: swara_sukma_lelaki@yahoo.co.id
}

(diterima 21 Juli 2013, disetujui 30 September 2013, revisi terakhir 11 November 2013)

\begin{abstract}
Abstrak
Dalam penelitian ini, upaya peningkatan pembelajaran apresiasi sastra difokuskan pada apresiasi drama yang dikhususkan pada kegiatan menulis kreatif naskah drama. Penelitian ini bertujuan untuk mendeskripsikan bentuk pembelajaran menulis naskah drama dengan strategi menulis terbimbing (SMT) yang efektif untuk memahamkan siswa tentang struktur naskah dan membentuk kemampuan siswa menulis naskah drama. Penelitian ini merupakan penelitian tindakan kelas (action research) dengan rancangan penelitian kualitatif yang dilaksanakan melalui tiga tahap, yaitu tahap (i) perencanaan pembelajaran, (ii) pelaksanaan pembelajaran, (iii) evaluasi hasil pembelajaran. Hasil penelitian ini menunjukkan bahwa bimbingan dalam bentuk pemberian model naskah drama dan kartu struktur naskah yang tepat serta pemberian variasi strategi belajar dan praktik berbagi hasil, telah mampu mengarahkan siswa menulis naskah drama dengan beragam tema; dengan keringkasan, ketepatan, dan kelengkapan pemaparan perwatakan pelaku; dengan latar yang ringkas, nyata, khusus, dan lengkap; serta dengan penggarapan konflik yang hidup.
\end{abstract}

Kata kunci: menulis kreatif, naskah drama, menulis terbimbing

\begin{abstract}
In this study, the efforts to increase the teaching and learning literary appreciation was focused on plays appreciation which was devoted to the activities of creative writing plays. This study was aimed at describing the form of learning to write a play with a guided writing strategy (SMT) which was found to be effective to promote the students' understanding about the structure of the text and to shape the students' ability to write a play. This research was class action (action research) and qualitative research design was implemented through three stages, namely the stage (i) learning plan, (ii) the implementation of learning, (iii) the evaluation of learning. These results indicate that the guidance in the form of models and correct script structure cards and the provision of variety of learning strategies and practices to share the results, have been able to direct the students to write a play with a variety of themes concisely, accurately and with completeness of exposure of characterization in a concise, tangible, specific, and complete background, as well as with the ability to grow alive conflicts.
\end{abstract}

Keywords: creative writing, playscript, guided writing

\section{PENDAHULUAN}

\subsection{Latar Belakang}

Dalam pembelajaran bahasa dan sastra Indonesia, sejauh ini pembelajaran sastra belum mendapatkan perhatian semestinya dibandingkan dengan pembelajaran bahasa Indonesia. Dalam khazanah pembelajaran sastra pun terdapat ketimpangan atau ketidakseimbangan yang disebabkan konsentrasi pembelajaran sastra yang cenderung mengarah pada apresiasi puisi dan prosa fiksi. Hal inilah yang mengakibatkan pembelajaran apresiasi drama kurang dikenal atau tidak populer di kalangan siswa.

Permasalahan umum yang melatarbelakangi kedua realitas di atas adalah kompetensi guru dalam mengajar sastra, lebih khusus mengajar drama. Bagi sebagian guru, mengajar sastra merupakan pekerjaan yang tidak mudah sehingga jalan pintas yang dilakukan adalah melewati materi ini begitu saja. Ada pula sebagian guru yang tetap mengajarkan materi ini secara terintegrasi dengan materi kebahasaan, meskipun hanya menyentuh bagian permukaan sastra 
(berteori) tanpa menyinggung substansi (apresiasi). Hal ini yang sering mengakibatkan pembelajaran sastra kehilangan orientasi, yakni sebagai pembelajaran yang memberikan "ruang" apresiasi dan produksi karya sastra. Untuk itu, diperlukan sebuah strategi khusus yang dapat membantu mengatasi kesulitan guru dalam mengajar drama sekaligus dapat mengoptimalkan kemampuan siswa.

Dari berbagai strategi yang ada, strategi menulis terbimbing (yang selanjutnya disingkat SMT) dapat dioptimalkan penggunaanya untuk meningkatkan apresiasi drama, dalam hal ini menulis naskah drama. Mengacu kepada fakta yang ada bahwa pembelajaran menulis naskah drama di sekolah menegah atas (SMA) masih berorientasi pada produk, bagaimana proses melahirkan produk naskah drama tersebut tentunya belum tergarap dengan baik. Karena itu, pembelajaran menulis naskah drama dengan SMT yang berorientasi pada pendekatan proses, secara potensial diharapkan dapat memperbaiki pembelajaran apresiasi drama pada khususunya dan kualitas pembelajaran sastra pada umumnya. Pendekatan SMT melibatkan proses berpikir dan proses menulis melalui beberapa tahapan, yaitu (i) pramenulis, (ii) menulis draf, (iii) menulis, (iv) merevisi, dan (v) publikasi.

Selain pendekatan proses, pendekatan lain yang secara mekanis difungsikan dalam penelitian ini adalah pendekatan integratif. Pendekatan ini digunakan karena fakta menjelaskan bahwa sejauh ini menulis naskah drama disikapi guru sebagai kegiatan isolatif yang tidak mengintegrasikan segenap komponen keterampilan berbahasa. Padahal, data dan informasi yang digunakan sebagai bahan menulis umumnya diperoleh melalui kegiatan berbahasa yang lain, khususnya membaca. Implikasi model pembelajaran apresiasi drama yang tak terintegrasi sebagaimana disebutkan akan menghasilkan naskah drama dengan ungkapan dialog yang kering, normatif, umum, dan tidak berbobot dramatik.

\subsection{Masalah}

Permasalahan umum yang akan dibahas dalam penelitian ini adalah bagaimanakah perencanaan, pelaksanaan, dan penilaian pembelajaran menulis naskah drama dengan SMT yang efektif untuk meningkatkan kemampuan siswa SMA dalam menulis naskah drama. Secara khusus, masalah penelitian ini adalah (1) bagaimana mendeskripsikan perencanaan pembelajaran menulis naskah drama dengan SMT tahap pembentukan pemahaman siswa SMA tentang struktur naskah dan cara menggarapnya melalui kegiatan membaca model, (2) bagaimana mendeskripsikan perencanaan pembelajaran menulis naskah drama dengan SMT tahap pembentukan kemampuan siswa SMA menentukan penggarapan struktur naskah melalui kegiatan menulis sebagai proses, (3) bagaimana mendeskripsikan pelaksanaan pembelajaran menulis naskah drama dengan SMT untuk membentuk pemahaman siswa SMA tentang struktur naskah dan kemampuan siswa menerapkan pemahamannya dalam kegiatan menulis, dan (4) bagaimana mendeskripsikan hasil pembelajaran menulis naskah drama dengan SMT tahap pembentukan pemahaman siswa SMA tentang struktur naskah drama dan kemampuan siswa menentukan struktur naskah dalam menulis naskah drama.

\subsection{Tujuan}

Penelitian ini secara umum bertujuan mendeskripsikan pembelajaran menulis naskah drama dengan SMT yang efektif untuk memahamkan siswa SMA tentang struktur naskah drama dan mengarahkan siswa agar menulis naskah dengan proses yang terintegrasi. Secara khusus, tujuan penelitian ini adalah (1) mendeskripsikan perencanaan pembelajaran menulis naskah drama dengan SMT tahap pembentukan pemahaman siswa SMA tentang struktur naskah dan cara menggarapnya melalui kegiatan membaca model, (2) mendeskripsikan perencanaan pembelajaran menulis naskah drama dengan SMT tahap pembentukan kemampuan siswa SMA menentukan penggarapan struktur naskah melalui kegiatan menulis sebagai proses, (3) mendeskripsikan pelaksanaan pembelajaran menulis naskah drama dengan SMT untuk membentuk pemahaman siswa SMA tentang struktur naskah dan kemampuan siswa menerapkan pemahamannya dalam kegiatan menulis, dan (4) mendeskripsikan hasil pembelajaran menulis naskah drama dengan SMT tahap pembentukan pemahaman siswa SMA tentang struktur naskah drama dan kemampuan siswa 
menentukan struktur naskah dalam menulis naskah drama.

\subsection{Metode}

Penelitian ini bertujuan memaparkan data verbal dan nonverbal berupa perilaku siswa dan guru SMA serta hasil kerja siswa dalam pembelajaran menulis naskah drama dengan SMT. Oleh karena itu, pendekatan penelitian yang digunakan adalah pendekatan kualitatif. Jenis penelitian yang digunakan adalah penelitian tindakan. Penggunaan metode penelitian tindakan dilakukan dengan mengidentifikasi gagasan umum yang dispesifikasikan sesuai dengan tema penelitian. Spesifikasi gagasan tersebut lebih lanjut digarap melalui empat tahapan secara berdaur mulai dari perencanaan, pelaksanaan tindakan, pengamatan, dan refleksi (perenungan, pemikiran, evaluasi), (Kemmis dan McTaggart dalam Hopkins, 1993).

Penelitian tindakan merupakan kajian tentang situasi sosial dengan maksud untuk meningkatkan kualitas praktik, yaitu kualitas praktik pembelajaran. McNiff (1992:4) menganggap bahwa penelitian tindakan adalah suatu strategi untuk meningkatkan pendidikan melalui perubahan dengan mendorong guru untuk menyadari dan kritis terhadap praktik mengajar mereka dan siap terhadap perubahan. Penelitian tindakan ini terfokus pada aktivitas pembelajaran di kelas sehingga penelitian ini berupa penelitian tindakan kelas (PTK).

Penelitian tindakan kelas bertujuan untuk memecahkan masalah-masalah praktis yang bersumber dari proses pembelajaran menulis naskah drama yang dilaksanakan di kelas. Kasbolah (2000:2) menyatakan bahwa penelitian tindakan kelas adalah penelitian praktis yang dimaksudkan untuk memperbaiki pembelajaran di kelas. Selanjutnya, Oja dan Smuljan (dalam Rofiuddin, 2002:15) menyatakan bahwa penelitian tindakan kelas memiliki ciri (i) bersifat kolaboratif, (ii) berfokus pada problem praktis, (iii) penekanan pada pengembangan profesional, dan (iv) memerlukan adanya struktur proyek yang memungkinkan partisipan untuk berkomunikasi.

Kolaborasi merupakan bentuk kerja sama yang memungkinkan lahirnya kesamaan pemahaman. Pada waktu berkolaborasi juga terjadi serangkaian kerja sama dan komunikasi yang dilakukan bersama praktisi untuk menghindari kesalahan pemahaman dan perbedaan pandangan yang bersumber dari perbedaan posisi di lapangan. Kerja sama dan komunikasi tersebut juga diperlukan untuk mendiskusikan dan mencari jalan keluar untuk mengatasi hambatanhambantan yang mungkin terjadi pada waktu pelaksanaan penelitian pembelajaran menulis naskah drama dengan SMT. Hasil diskusi yang dilakukan dengan guru bidang studi akan dijadikan bahan acuan untuk memperbaiki tahapan penelitian selanjutnya. Selain itu, hubungan positif dengan sekolah akan turut memengaruhi berhasil tidaknya penelitian tindakan kelas yang dilakukan.

Dalam penelitian tindakan kelas ini, masalah yang diteliti terfokus pada kemampuan siswa SMA dalam menulis naskah drama. Masalah yang diteliti berupa problem praktis yang berasal dari siswa. Penelitian ini memungkinkan guru untuk mendapatkan tambahan ilmu pengetahuan berupa perubahan dalam pembelajaran menulis naskah drama dengan SMT di kelas. Selain itu, hal ini membantu guru dalam memecahkan masalah pembelajaran menulis naskah drama secara profesional dengan SMT yang sudah diketahui dan dapat diaplikasikan pada masa mendatang.

Penelitian tindakan kelas ini dilakukan sebagai upaya menemukan bentuk pembelajaran menulis naskah drama dengan menggunakan SMT yang efektif untuk memahamkan siswa tentang struktur naskah dan penggarapanya. Proses pelaksanaannya dimulai dengan mengidentifikasi masalah-masalah pembelajaran menulis naskah drama yang ditemui di kelas. Setelah permasalahan teridentifikasi, dilakukan penyusunan perencanaan, pelaksanaan tindakan, observasi atau pengamatan, dan refleksi dengan menggunakan siklus yang bersifat spiral sehingga memungkinkan untuk dimodifikasi apabila diperlukan. Tahapan penelitian tindakan oleh Kurt Lewin (dalam Elliot, 1991) disebut siklus dasar yang meliputi identifikasi ide awal, analisis, penemuan masalah umum, perencanaan tindakan, pengembangan langkah tindakan pertama, pelaksanaan tindakan pertama, evaluasi dan refleksi serta penyempurnaan dan perbaikan perencanaan umum.

Dari studi pendahuluan, siswa SMA diketahui masih kesulitan dalam menulis naskah drama. Mereka 
tidak dapat mengembangkan ide, gagasan, pikiran, dan imajinasi mereka dengan baik. Mereka juga kurang memahami materi menulis naskah drama yang diberikan guru. Hal tersebut mengakibatkan rendahnya kemampuan siswa dalam menulis naskah drama. Berdasarkan hasil karangan siswa yang sudah pernah dilakukan, diketahui bahwa siswa kurang mampu menulis naskah drama dengan baik. Hal ini terlihat dari ketidakjelasan pengembangan alur dan karakterisasi tokoh, ketidakmenarikan tema, dan ketidakjelasan latar. Oleh karena itu, diperlukan sebuah strategi khusus yang dapat diterapkan dalam pembelajaran menulis naskah drama agar kemampuan siswa dalam menulis naskah drama dapat meningkat dan dapat dioptimalkan.

Berdasarkan identifikasi masalah yang diperoleh dari studi pendahuluan, (i) dirumuskan masalah penelitian yang akan diberi tindakan, (ii) disusun rencana tindakan, (iii) pelaksanaan tindakan yang dilakukan sebanyak $n$ siklus (setiap siklus tindakan yang dilakukan disesuaikan dengan keberhasilan pada siklus I), (iv) pengamatan untuk merekam berbagai data dan kendala yang dihadapi berkaitan dengan pembelajaran menulis naskah drama dengan menggunakan SMT dengan memanfaatkan instrumen pedoman observasi, pedoman wawancara, dan pedoman studi dokumentasi berupa hasil tulisan siswa, dan (v) refleksi setiap akhir pertemuan pada setiap tahap pembelajaran untuk dikaji dan dibahas bersama dengan praktisi seluruh informasi yang berhasil dihimpun. Data dalam penelitian ini berbentuk data hasil proses dan data hasil produk. Data hasil penelitian diperoleh melalui kegiatan pengamatan, wawancara, dan pencatatan lapangan pada saat berlangsungnya proses menulis dengan menggunakan SMT. Data hasil penelitian ini berupa data verbal dan data nonverbal. Data diperoleh dari sumber yang diteliti, yaitu siswa dan guru. Siswa dan guru yang menjadi sumber data dalam penelitian ini adalah siswa dan guru kelas XI Jurusan Bahasa SMA 5 Malang, Jawa Timur.

Teknik pengumpulan data yang digunakan dalam penelitian ini adalah teknik observasi, wawancara, dan studi dokumentasi. Instrumen penelitian berupa instrumen utama dan instrumen penunjang. Instrumen utama adalah peneliti, sedangkan instrumen penunjang berupa pedoman observasi, catatan lapangan, dokumentasi, indikator penulisan naskah yang baik, dan foto.

Pengecekan keabsahan data perlu dilakukan untuk mengetahui bahwa data yang diambil benar-benar valid sekaligus untuk menghindari data yang tumpang tindih. Dalam penelitian ini, pengecekan keabsahan data dilakukan dengan ketekunan pengamatan, trianggulasi metode, dan pengecekan teman sejawat. Selanjutnya, teknik analisis data model mengalir (Miles dan Huberman, 1992:18) digunakan dalam penelitian ini. Kegiatan analisis data secara garis besar meliputi (i) menelaah seluruh data yang sudah terkumpul melalui observasi, wawancara, dan dokumentasi, (ii) mereduksi data meliputi pengategorian dan pengklasifikasian data, (iii) menyajikan data yang sudah direduksi, dan (iv) menyimpulkan data.

\section{KERANGKA TEORI}

\subsection{Proses Kreatif dalam Menulis}

Menulis merupakan suatu proses kreatif yang banyak melibatkan cara berpikir divergen (menyebar) daripada konvergen (memusat) (Supriadi, 1997). Kendati secara teknis ada kriteria-kriteria yang dapat diikutinya, tetapi wujud yang akan dihasilkan itu sangat bergantung pada kepiawaian penulis dalam mengungkapkan gagasan. Banyak orang mempunyai ide-ide bagus di benaknya sebagai hasil dari pengamatan, penelitian, diskusi, atau membaca. Akan tetapi, begitu ide tersebut dilaporkan secara tertulis, laporan itu terasa amat kering, kurang menggigit, dan membosankan. Fokus tulisannya tidak jelas, gaya bahasa yang digunakan monoton, pilihan katanya (diksi) kurang tepat dan tidak mengena sasaran, serta variasi kata dan kalimatnya kering.

Sebagai proses kreatif yang berlangsung secara kognitif, penyusunan sebuah tulisan memuat empat tahap, yaitu (i) tahap persiapan (prapenulisan), (ii) tahap inkubasi, (iii) tahap iluminasi, dan (iv) tahap verifikasi/evaluasi. Pertama, tahap persiapan atau prapenulisan adalah ketika pembelajar menyiapkan diri, mengumpulkan informasi, merumuskan masalah, menentukan fokus, mengolah informasi, menarik tafsiran dan inferensi terhadap realitas yang dihadapinya, berdiskusi, membaca, mengamati, dan lain-lain yang memperkaya masukan kognitifnya yang akan diproses selanjutnya. 
Kedua, tahap inkubasi adalah ketika pembelajar memproses informasi yang dimilikinya sedemikian rupa sehingga mengantarkannya pada ditemukannya pemecahan masalah atau jalan keluar yang dicarinya. Proses inkubasi ini dianalogikan dengan ayam yang mengerami telurnya sampai telur menetas menjadi anak ayam. Proses ini seringkali terjadi secara tidak disadari dan memang berlangsung dalam kawasan bawah sadar (subconscious) yang pada dasarnya melibatkan proses perluasan pikiran (expanding of the mind). Proses ini dapat berlangsung beberapa detik sampai bertahun-tahun. Biasanya, ketika seorang penulis melalui proses ini seakan-akan ia mengalami kebingungan dan tidak tahu apa yang harus dilakukan. Oleh karena itu, tidak jarang seorang penulis yang tidak sabar mengalami frustrasi karena tidak menemukan pemecahan atas masalah yang dipikirkannya. Seakan-akan kita melupakan apa yang ada dalam benak kita. Kita berekreasi dengan anggota keluarga, melakukan pekerjaan lain, atau hanya duduk termenung. Kendati demikian, sesungguhnya di bawah sadar kita sedang mengalami proses pengeraman yang menanti saatnya untuk segera "menetas".

Ketiga, tahap iluminasi adalah ketika datangnya inspirasi (insight), yaitu gagasan datang seakan-akan tiba-tiba dan berloncatan dari pikiran kita. Pada saat ini, apa yang telah lama kita pikirkan menemukan pemecahan masalah atau jalan keluar. Iluminasi tidak mengenal tempat atau waktu. Ia bisa datang ketika kita duduk di kursi, sedang mengendarai mobil, sedang berbelanja di pasar atau di supermarket, sedang makan, sedang mandi, dan lain-lain.

Jika hal-hal itu terjadi, sebaiknya gagasan yang muncul dan amat dinantikan itu segera dicatat, jangan dibiarkan hilang kembali sebab momentum itu biasanya tidak berlangsung lama. Tentu saja untuk peristiwa tertentu, kita menuliskannya setelah selesai melakukan pekerjaan. Jangan sampai ketika kita sedang mandi, misalnya, kemudian keluar hanya untuk menuliskan gagasan. Agar gagasan tidak menguap begitu saja, seorang pembelajar-menulis yang baik selalu menyediakan pulpen atau pensil dan kertas di dekatnya, bahkan dalam tasnya ke mana pun ia pergi.

Sering orang menganggap iluminasi ini sebagai ilham. Padahal, sesungguhnya ia telah lama atau pernah memikirkannya. Secara kognitif, apa yang dikatakan ilham tidak lebih dari proses berpikir kreatif. Ilham tidak datang dari kevakuman, tetapi dari usaha dan ada masukan sebelumnya terhadap referensi kognitif seseorang.

Keempat, tahap terakhir, yaitu verifikasi, apa yang dituliskan sebagai hasil dari tahap iluminasi itu diperiksa kembali, diseleksi, dan disusun sesuai dengan fokus tulisan. Mungkin ada bagian yang tidak perlu dituliskan, atau ada hal-hal yang perlu ditambahkan, dan lain-lain. Mungkin juga ada bagian yang mengandung hal-hal yang peka sehingga perlu dipilih kata-kata atau kalimat yang lebih sesuai, tanpa menghilangkan esensinya. Jadi, pada tahap ini kita menguji dan menghadapkan apa yang kita tulis itu dengan realitas sosial, budaya, dan norma-norma yang berlaku dalam masyarakat.

\subsection{Pembelajaran Menulis sebagai Sebuah Proses}

Menulis sebagai sebuah proses mengandung makna bahwa menulis meliputi serangkaian aktivitas yang aktif dan dinamis. Rangkaian aktivitas tersebut tidak berurutan secara ketat, tetapi bersifat luwes dan berulang-ulang. Flowers dan Hayes (dalam Marzano, 1992:57) mengatakan bahwa proses menulis tidak bersifat linier, tetapi bersifat interaktif dan recursive. Hal ini berarti bahwa dalam proses menulis, antara tahap yang satu dengan tahap yang lain saling berkaitan dan berulang secara fleksibel. Zuchdi (1997:6) mengatakan bahwa tahap-tahap dalam menulis bukanlah tahap yang bersifat linear karena penulis terus-menerus memantau tulisannya dan bergerak maju mundur. Peninjauan kembali tulisan yang telah dihasilkan ini dapat dianggap sebagai komponen keempat dalam proses menulis. Hal inilah yang membantu penulis dapat mengungkapkan gagasan secara logis dan sistematis, tidak mengandung bagian-bagian yang kontradiktif. Dengan kata lain, keajegan (konsistensi) isi gagasan dapat terjaga.

Mengenai tahapan-tahapan dalam menulis, Tompkins (1994) dan Ellis (1989) menguraikan lima tahapan proses menulis. Kelima tahap tersebut yaitu pramenulis (prewriting), penyusunan dan penerapan konsep (drafting), perbaikan (revising), penyuntingan (editing), dan penerbitan (publishing). Adapun Hamp- 
Lyons dan Heasbey (1987) mengemukakan tiga tahapan proses menulis yakni pramenulis, menulis, dan menulis kembali. Selanjutnya, Cox (1999:319327) menyebutkan lingkungan literasi, pemodelan, workshop menulis, konferensi, perevisian dan pengeditan, serta pemublikasian sebagai bagianbagian penting dalam proses pembelajaran menulis. Dengan demikian, proses menulis pada dasarnya merupakan sebuah kegiatan produktif yang terdiri atas beberapa level aktivitas yang bermuara pada hasil atau produk tulisan. Setiap level aktivitas tentunya berisi kegiatan kolaboratif antara siswa dengan guru maupun sesama siswa.

Menulis merupakan keterampilan mekanis yang dapat dipahami dan dipelajari. Tahapan-tahapan yang telah disebutkan sebelumnya dapat mempermudah pemahaman dan pemerolehan keterampilan yang dimaksud. Lima tahapan menulis sebagaimana yang telah diuraikan Tompkins akan menjadi acuan dalam penelitian ini. Kelima tahapan tersebut merupakan pengalaman yang harus dilakukan dalam mengonstruksi sebuah teks dan sudah barang tentu memiliki aktivitas serta strategi masing-masing. Masing-masing aktivitas dan strategi dalam lima tahapan proses menulis akan diuraikan sebagai berikut.

\subsubsection{Tahap Pembelajaran Pramenulis}

Pramenulis merupakan tahapan esensial dalam menulis. Menurut Murray (dalam Thompkins, 1991:9), pramenulis memegang peran penting dan menentukan keberhasilan pembelajaran. Kegiatan pembelajaran dalam tahap ini meliputi (a) penjabaran topik berdasarkan tema, (b) pemilihan topik sesuai tema, (c) pengembangan topik, (d) penulisan judul, dan (e) penyusunan kerangka karangan. Selanjutnya, strategi yang dilakukan guru dalam membantu dan mengarahkan siswa untuk melakukan kegiatan pramenulis adalah sebagai berikut.

\section{1) Sumbang Saran}

Untuk menentukan pokok permasalahan yang akan ditulis, siswa dapat melakukan penjajagan ide melalui sumbang saran (Syafi'ie, 1994). Melalui sumbang saran, siswa dapat menggali skemata, pengetahuan, dan pengalamannya dalam menentukan topik yang ditulis. Pelaksanaan sumbang saran dapat melalui langkah-langkah, (a) guru menentukan tema berdasarkan kurikulum, minat, pengetahuan siswa, atau pertimbangan tertentu, (b) guru mengadakan tanya jawab dengan siswa untuk menggali dan mencurahkan gagasan, pengalaman, minat, hobi, serta skemata siswa yang berhubungan dengan tema secara tertulis atau lisan dan dengan tidak mengadakan koreksi terhadap jawaban siswa, (c) mengelompokkan jawaban yang relevan dengan tema berdasarkan tanya jawab yang dilakukan. Selanjutnya, guru bersama siswa atau siswa secara berkelompok maupun secara individu menentukan topik yang digemarinya.

\section{2) Pengelompokan}

Pengelompokan merupakan pemetaan sebelum menulis draf yang memudahkan siswa dalam melihat hubungan tema dengan topik, antara topik dengan gagasan, dan antara gagasan pokok dengan detail penjelasnya. Strategi ini dapat menjadi dasar penyusunan kerangka karangan.

Tompkins (1991) menyarankan penggunaan beberapa bentuk pengelompokan. Bentuk-bentuk tersebut meliputi (a) pengelompokan cerita, (b) pengelompokan $5 \mathrm{~W}$, (c) pengelompokan laporan, (d) pengelompokan sensori detail.

\subsubsection{Tahap Pembelajaran Pengedrafan}

Pada tahap ini, siswa mengembangkan garis besar cerita yang telah disusun berdasarkan tema ke dalam draf. Strategi pengenalan model teks dapat digunakan guru untuk membantu dan membimbing siswa dalam menulis draf. Cox (1990:319) menyatakan bahwa pemodelan adalah bagian yang penting dalam pengajaran menulis. Guru dapat memberi model tentang kenikmatan menulis dan latihan menulis dengan cara memberi contoh dan pilihan teks bacaan.

\subsubsection{Tahap Pembelajaran Perevisian}

Yang perlu dilakukan oleh siswa pada tahap merevisi tulisan ini adalah (a) berbagi tulisan dengan teman-teman (kelompok), (b) berpartisipasi secara konstruktif dalam diskusi tentang tulisan teman-teman sekelompok atau sekelas, (c) mengubah tulisan mereka dengan memperhatikan reaksi dan komentar baik dari pengajar maupun teman, (d) memperhatikan pementasan dan input lokakarya pascapentas, serta (d) membuat perubahan yang substantif pada draf 
pertama dan draf berikutnya sehingga menghasilkan draf akhir.

\subsubsection{Tahap Pembelajaran Penyuntingan}

Pada tahap menyunting, siswa dapat (a) membetulkan kesalahan bahasa tulisan mereka sendiri, (b) membantu membetulkan kesalahan bahasa dan tata tulis tulisan teman sekelas/sekelompok, dan (c) mengoreksi kembali kesalahan-kesalahan tata tulis tulisan mereka sendiri.

\subsubsection{Tahap Pembelajaran Pemublikasian}

Tahap terakhir dalam proses menulis adalah berbagi hasil (sharing) atau publikasi. Pada tahap berbagi ini, siswa dapat memublikasikan (memajang) tulisan mereka, berbagi tulisan yang dihasilkan dengan pembaca yang telah mereka tentukan, dan dalam konteks penulisan naskah drama, siswa dapat membaca naskah dan atau mementaskan.

\subsection{Integrasi Keterampilan Membaca dan Menulis}

Keterampilan menulis terkait dengan keterampilan berbahasa lainnya. Dalam kaitannya dengan keterampilan membaca, keterampilan menulis tentunya berhubungan resiprokal dan saling mendukung dengan keterampilan membaca. Jika menulis merupakan cara untuk mengomunikasikan pikiran dan perasaan, untuk memperoleh informasi yang berkaitan dengan bentuk tulisan atau topik yang akan ditulis diperlukan kegiatan membaca.

Pada saat proses menulis berlangsung, siswa melakukan kegiatan membaca sebagai kegiatan dari latihan pramenulis. Untuk menguji pemahaman membacannya, siswa melakukan kegiatan menulis kembali isi teks yang telah dibacanya. Setelah membaca naskah drama, untuk mengungkapkan hasil pemahamannya berkaitan dengan struktur naskah drama, siswa melakukan kegiatan menulis kembali penggarapan struktur naskah yang telah dipahaminya. Pada saat yang sama yakni saat kegiatan menulis berlangsung, siswa juga melakukan kegiatan pramembaca untuk mengetahui kebermaknaan dari topik yang telah ditulisnya.

Membaca merupakan proses merekonstruksi makna melalui bahasa tertulis. Membaca merupakan pengembangan atau bertemunya skemata isi yang dimiliki si anak (pengetahuan dan pengalaman sebelumnya) dengan informasi (kode yang tertuang dalam teks). Membaca merupakan suatu proses memahami cetakan (print-out) yang diarahkan oleh dunia pengalaman dan pengetahuan pembacanya. Proses membaca dapat diasumsikan sebagai proses menerjemahkan cetakan sebagai sistem tanda sehingga menghadirkan gambaran makna dan pengertian-pengertian tertentu. Kegiatan yang lazim disebut decoding itu ditandai oleh terdapatnya proses identifikasi tulisan, kata-kata, kalimat, sampai ke rekonstruksi makna dalam konteks dan teks (Aminuddin, 1996). Dalam proses membaca, pemahaman didasarkan pada cetakan dan ditentukan oleh pengalaman dan pengetahuan yang dimiliki pembaca sebagai skemata.

Pada saat membaca naskah drama, siswa merekonstruksi gagasan-gagasan dan makna yang termuat dalam bacaan berkaitan dengan struktur naskah dan penggarapannya. Berdasarkan hasil rekonstruksi makna ini, siswa melakukan kegiatan pramenulis melalui kegiatan menulis naskah dengan penggarapan struktur naskah yang tepat. Dari hasil tulisan siswa dapat dilihat bentuk keseluruhan pemahaman siswa berkaitan dengan isi bacaan, dalam hal ini penggarapan struktur.

\section{HASIL DAN PEMBAHASAN}

Hasil penelitian yang berkaitan dengan perencanaan PBM berdasarkan SMT menunjukkan bahwa perencanaan pembelajaran menulis naskah drama dengan strategi menulis terbimbing dilakukan dalam dua tahap. Tahap tersebut meliputi tahap kegiatan membaca untuk memperoleh pemahaman terhadap struktur naskah dan cara penggarapanya serta tahap kegiatan menulis untuk mengembangkan kemampuan siswa menulis naskah drama berdasarkan pemahaman yang diperolehnya dari aktivitas membaca. Selanjutnya, bimbingan yang direncanakan berupa (i) pemberian model naskah drama, (ii) penggunaan kartu struktur naskah, (iii) strategi belajar individual dan kelompok, (iv) teknik konferensi, (v) pementasan, dan (vi) berbagi hasil kerja, sudah mengarahkan siswa memahami struktur naskah.

Hasil penelitian yang berkaitan dengan pelaksanaan PBM dengan SMT antara lain (i) kegiatan membaca model naskah drama membekali siswa dalam memahami struktur naskah dan cara 
penggarapannya, (ii) terdapat kecenderungan perencanaan penulisan naskah drama yang semakin lengkap dan hasil tulisan yang semakin baik setelah siswa membaca beberapa naskah model, (iii) kartu struktur naskah memudahkan siswa memahami dan mempermudah penentuan struktur naskah, (iv) peralihan dari strategi belajar individual ke belajar kelompok memunculkan permasalahan umum tentang keterlibatan siswa. Tingkat keterlibatan yang tidak merata dalam kelompok bersumber dari pembagian peran yang tidak jelas dan respon guru yang tidak optimal, (v) kegiatan pemanfaatan model naskah sebagai hasil dari pemahaman membaca mengarahkan siswa agar menulis cerita secara baik sebagaimana model yang mereka baca. Pada tahap awal pemanfaatan model untuk menulis, siswa melakukan peniruan pada unsur-unsur tertentu dalam struktur naskah, tetapi demikian tidak semua siswa memanfaatkan model cerita, dan (vi) sumbang saran, pengelompokan cerita, pengedrafan, perevisian, pemublikasian telah mampu mengarahkan siswa menulis naskah drama dengan lebih efektif.

Hasil penelitian yang berkaitan dengan produk naskah drama melalui SMT menunjukkan bahwa (i) siswa telah mampu menulis naskah drama dengan tema yang original dan bervariatif (kualifikasi baik), perwatakan pelaku secara ringkas, tepat, dan lengkap (kualifikasi sangat baik), latar secara ringkas, nyata, khusus, dan lengkap (kualifikasi baik), plot yang runtut dan potensial menciptakan konflik (kualifikasi baik), dan (ii) secara umum kualitas naskah dikategorikan menjadi tiga, yaitu naskah yang layak dipentaskan, naskah yang tidak layak dipentaskan, dan naskah yang belum layak dipentaskan tetapi sudah bagus sebagai sebuah naskah.

Perencanaan pembelajaran menulis naskah drama dengan strategi menulis terbimbing yang dilakukan dalam tahap kegiatan membaca untuk memperoleh pemahaman terhadap struktur naskah dan tahap menulis naskah drama berdasarkan pemahaman yang diperolehnya dari aktivitas membaca, efektif membentuk pemahaman terhadap struktur naskah sebagai bekal menulis naskah drama. Bimbingan yang direncanakan berupa (i) pemberian model naskah drama, (ii) penggunaan kartu struktur naskah, (iii) strategi belajar individual dan kelompok, (iv) teknik konferensi, (v) pementasan, dan (vi) berbagi hasil kerja, juga sudah mengarahkan siswa agar memahami struktur naskah dan membimbing proses penulisan.

Pada pelaksanaan PBM, kegiatan membaca model naskah drama membekali siswa dalam memahami struktur naskah dan cara penggarapannya. Tompkins (1994), Gordons dan Braun's (1982) menyebutkan bahwa pemberian skemata tentang struktur cerita melalui kegiatan membaca dan menelaah struktur cerita dalam model membuat siswa memahami penggarapan struktur cerita. Penggunaan kartu struktur naskah juga memudahkan siswa memahami struktur naskah sebagaimana Robinson (1980) menyatakan bahwa penggunaan kartu (chart) struktur cerita memudahkan siswa dalam menulis cerita.

Selanjutnya, peralihan dari strategi belajar individual ke belajar kelompok memunculkan permasalahan umum tentang keterlibatan siswa. Tingkat keterlibatan yang tidak merata dalam kelompok bersumber dari pembagian peran yang tidak jelas dan respon guru yang tidak optimal. Permasalahan di atas dapat diatasi dengan menciptakan iklim kelas yang baik dengan cara mengharuskan guru bersikap tanggap, membagi perhatian, memusatkan perhatian kelompok/kelas, dan memberi petunjuk yang jelas. Pertanyaan yang mengarahkan dan menggali dapat digunakan untuk memfokuskan perhatian dan pemikiran siswa sebagaimana Moody dan Elkins (dalam Waluyo, 2001:176) yang menekankan pentingnya pertanyaan yang terarah dan menggali agar siswa menemukan makna dalam sebuah pembelajaran (inquiri).

Sumbang saran, pengelompokan cerita, pengedrafan, perevisian, pemublikasian telah mampu mengarahkan siswa menulis naskah drama dengan lebih efektif. Mengenai sumbang saran, Syafi'ie (1988) dan Syanahan (1990) menyampaikan bahwa aktivitas ini dapat membantu siswa menuangkan ide dan memilih tema. Rico dalam Tompkins (1994) menyebutkan bahwa pembuatan kelompok cerita mengarahkan siswa agar mampu mengembangkan tema cerita. Lebih lanjut, tujuan pementasan telah mampu memotivasi siswa dalam menulis naskah drama. Pementasan juga menjadi dasar pijak perevisian yang cukup efektif untuk menyempurnakan naskah drama siswa. Berkaitan dengan ini, Waluyo (2001:175) berpendapat bahwa teknik penyampaian (publikasi) dalam pengajaran drama dapat berupa (i) 
mendiskusikan naskah drama untuk menghasilkan kesimpulan tentang struktur dramatiknya dan kemungkinan pementasan; (ii) mementaskan sebuah adegan; dan (iii) mementaskan sebuah lakon.

Hasil pembelajaran menulis naskah drama menunjukkan bahwa siswa telah mampu menulis naskah drama dengan (i) tema yang orisinal dan bervariatif dengan kualifikasi baik, (ii) perwatakan pelaku secara ringkas, tepat, dan lengkap dengan kualifikasi sangat baik, (iii) latar secara ringkas, nyata, khusus, dan lengkap dengan kualifikasi baik, dan (iv) plot yang runtut dan potensial menciptakan konflik dengan kualifikasi baik.

Hasil pembelajaran sebagaimana terpapar di atas tidak lepas dari bimbingan selama proses penulisan. Bimbingan yang terbukti mampu meningkatkan kemampuan siswa menulis naskah drama berupa aktivitas membaca model naskah drama, sumbang saran, pengelompokan cerita, dan berbagi hasil. Aktivitas berbagi hasil, baik dalam bentuk diskusi kelompok, diskusi kelas, maupun pementasan sebagai salah satu bentuk bimbingan dalam proses penulisan senantiasa menyediakan ruang untuk bertukar ide, beradu pendapat, dan berbagi temuan. Pada akhir kegiatan, guru selalu memberikan balikan atas hasil aktivitas berbagi siswa. Dalam pembelajaran keterampilan proses, dalam hal ini proses menulis naskah drama, guru diharapkan dapat memberikan balikan selama siswa menulis sehingga siswa dapat memanfaat-kannya untuk memperbaiki tulisannya (Tompkins, 1990).

Secara umum, kualitas naskah drama yang dihasilkan siswa dikategorikan menjadi tiga, yaitu naskah yang layak dipentaskan, naskah yang tidak layak dipentaskan, dan naskah yang belum layak dipentaskan tetapi sudah bagus sebagai sebuah naskah. Kualitas hasil yang demikian ditentukan dengan mengacu kepada pedoman penulisan naskah drama. Pedoman penulisan naskah drama memuat unsur-unsur pokok yang harus termuat dalam sebuah naskah sehingga layak untuk dipentaskan. Melalui pedoman ini diharapkan diperoleh gambaran hasil kemampuan siswa menulis naskah drama. Senada dengan pendapat Omaggio (dalam Rofi'uddin, 1996) bahwa evaluasi hasil dilakukan dengan cara menilai karangan dengan memerhatikan unsur-unsur yang diutamakan dalam jenis karangan cerita telah memberikan gambaran hasil tentang kemampuan siswa menulis sebuah cerita.

\section{PENUTUP}

\subsection{Simpulan}

Bimbingan yang berupa (i) pemberian model naskah drama, (ii) penggunaan kartu struktur naskah dan kartu revisi naskah pascapentas, (iii) penerapan strategi belajar individual dan kelompok, (iv) sumbang saran, dan (v) pementasan, dapat mengarahkan siswa menulis naskah drama dengan baik. Untuk itu, pada tahap perencanaan, guru harus dapat menentukan sarana dan stimulan yang cocok untuk siswa sehingga siswa mampu mengoptimalkan kemampuannya dalam menulis naskah drama. Guru juga harus memantau proses pemberian respon oleh siswa selama kegiatan menulis berlangsung. Berdasarkan respon tersebut, guru dapat merencanakan pemberian bimbingan menulis naskah drama yang lebih konkret dan praktis.

Pelaksanaan peran guru secara maksimal, baik sebagai perancang, motivator, fasilitator, model, pembimbing, stimulan, maupun konektor memungkinkan terciptanya iklim pembelajaran yang optimal sehingga berdampak pada keberhasilan pelaksanaan pembelajaran menulis naskah drama. Keberhasilan pelaksanaan pembelajaran menulis naskah drama dapat tercapai jika terdapat kesesuaian antara fakta, gejala, atau sesuatu yang dipelajari dengan tingkat perkembangan mental dan sosial budaya siswa. Kesesuaian tersebut memberi peluang terjadinya internalisasi berkenaan dengan sesuatu yang dipelajari dan peluang adaptasi dengan dasar pengetahuan yang dimiliki. Stimulan yang membentuk daya kognisi dan keterampilan siswa di atas diperoleh antara lain melalui aktivitas membaca dalam hati (apresiatif) dan membaca nyaring (ekspresif), pemberian model naskah drama, pemberian kartu struktur naskah, penggunaan strategi belajar kelompok dan belajar individual secara bervariasi, sumbang saran, pengelompokan cerita, observasi individual maupun kelompok oleh guru, pengedrafan dan perevisian, berbagi hasil, motif pementasan, dan pemberian indikator penulisan naskah.

Pembelajaran menulis naskah drama berdasarkan SMT dapat memampukan dan memahamkan siswa 
dalam hal (i) menentukan tema secara bervariatif berdasarkan idenya sendiri dan mengembangkannya menjadi sebuah naskah utuh; (ii) menentukan perwatakan pelaku secara ringkas, tepat, dan lengkap; (iii) menentukan latar secara ringkas, nyata, khusus, dan lengkap sehingga sangat potensial untuk ditampilkan dalam pementasan; dan (iv) menentukan tujuan, rintangan, dan taktik untuk menciptakan konflik yang hidup.

\subsection{Saran}

Berdasarkan simpulan di atas disarankan kepada guru Bahasa dan Sastra Indonesia yang mengajarkan kompetensi menulis naskah drama agar (i) menjadikan penelitian ini sebagai salah satu acuan dalam penerapan strategi menulis terbimbing sebagai upaya peningkatan apresiasi sastra, khususnya dalam pembelajaran menulis naskah drama dan (ii) memanfaatkan hasil penelitian ini sebagai alternatif perbaikan dan model pembelajaran menulis naskah drama.

Hasil penelitian ini memberikan penegasan bahwa menulis naskah drama bukanlah sebuah aktivitas yang sulit untuk dipelajari. Melalui tahapan bimbingan sebagaimana yang telah ditempuh siswa, potensi menulis mereka terbukti dapat dioptimalkan. Dengan demikian, kepada siswa disarankan agar (i) secara mandiri memanfaatkan tahapan-tahapan bimbingan tersebut dalam proses menulis naskah-naskah drama selanjutnya dan (ii) tidak selalu menjadikan bimbingan formal dari guru sebagai satu-satunya sumber dalam pembelajaran menulis naskah drama. Ketergantungan yang demikian dapat menghambat kreativitas mereka sendiri. Bimbingan naskah model, kerja mandiri dalam kelompok, dan pementasan mandiri dalam kenyataannya lebih berpotensi untuk mengoptimalkan kemampuan mereka.

Deskripsi hasil penelitian ini terbatas pada pembelajaran menulis naskah drama. Oleh karena itu, sebagai kelanjutan dari penelitian ini, dapat dilakukan penelitian dengan kajian yang sama, tetapi dalam fokus yang berbeda. Fokus penelitian yang tidak saja mengarah pada penulisan naskah, tetapi juga pada produksi kreatif berupa pementasan utuh dapat menjadi kajian yang dapat melengkapi penelitian ini.

\section{DAFTAR PUSTAKA}

Aminuddin. 1994. Pembelajaran Terpadu sebagai Bentuk Penerapan Kurikulum 1994 Mata Pelajaran Bahasa dan Sastra Indonesia. Malang: IKIP Malang. 1996. Pengajaran Melalui Penelitian Area Isi Teks Naratif. Malang: IKIP Malang.

Barnard, Erlin S. 1996. Application of Schema Theory in Teaching of Reading Using Authentic Materials. Padang: IKIP Padang.

BogdandanBiklen, 1998. Qualitative Research for Education: An Introduction on Theory and Method. Boston: Allyn and Bacon.

Cox, Carole. 1999. Teaching Language Art: A Student-and Response-Centered Classroom. Boston: Allyn \& Bacon

Depdikbud. 1993. Penelitian Tindakan. Jakarta: Depdikbud.

Depdiknas. 2003. Kurikulum 2004: Pedoman Umum Pengembangan Silabus Berbasis Kompetensi. Jakarta: Depdiknas.

Ellis, Arthur, dkk. 1989. Elementary Language Arts Instructions. New Jersey: Prentice Hall.

Hamp_Lyons dan Heasley. 1987. Study Writing. Cambridge: Cambridge University Press.

Hamzah, A. Ajib. 1985. Pengantar Bermain Drama. Bandung: CV Rosda.

Harymawan, R.M.A. 1974. Dramaturgi. Bandung: PT Remaja Rosdakarya.

Hill, Susan dan Tim Hill. 1993. The Collaborative Classroom. Eleanor Curtain Publishing Group.

Huck, Charlotte S. 1987. Children Literature in the Elementary School. New York: Hol Rinerhart. 
Jabrohim, dkk. 2001. Cara Menulis Kreatif. Yogyakarta: PustakaPelajar.

Marzano, Robert J. 1992. Dimensions of Thinking. ASCD. Alexandria: 125 New Street.

McNiff, Jean. 1992. Actions Research: A Short Modern History. Victoria: Deakin University Press.

Milles, M.B. \& Huberman, M.A. 1992. Analisis Data Kualitatif. Penerjemah: Tjetjep Rohendi Rohidi. Jakarta: UI.

Moore, W. D. dkk. 1986. Developing Readers and Writers in the Content Area: K-12. New York: Longman Inc.

Norton, Donna E. and Saundra Norton. 1994. Language Arts Activities for Children's. New York: MacMillan College Publising Company.

Nunan, David. 1991. LanguageTeaching Methodology: A Textbook for Teachers. New York Prentice Hall.

Olson, Carrol Booth. 1992. Thinking/Writing: Fostering Critical Thinking Through Writing. USA: Harper Collins Publisher.

Oxford, Rebecca L. 1990. Language Learning Strategies. Boston: Heinle \& Heinle Publisher.

Pamela, J.P. 1993. Language Arts a Process Approach. Dobeque: Win C. Brown Communication.

Papas, Cristine C. dkk. 1990. An Integrated Language Perspective in The Elementary School. London:Longman.

Pollard, A. dan Bourne, J. (Peny). 1994. Teaching and Learning in The Primary School. New York: The Open University.

Robinson, Alan H. dan Nila B. Smith. 1980. Reading Instructions for Today's Children. Prentice Hall International USA.

Rofi'uddin, A.H. 1994. Rancangan Penelitian Tindakan. Malang: Lemlit IKIP Malang.

Rofi'uddin. 1997. PengajaranMembaca dan MenulisPermulaan. Malang: PPS IKIP Madang.

Rofi'uddin. 2002. Metode Penelitian Kualitatif dalam Pengajaran Bahasa Indonesia. Malang: Fakultas Sastra $\mathrm{UM}$.

Routman, Regie. 1994. Invitations: Changing as Teacher and Learners K-12. Portsmount, NH: Heinemann.

Rubin, Dorothy. 1995. Teaching Elementary Language Arts: An Integrated Approach. Boston: Allynang Bacon.

Shanahnan, Timothy. 1990. Reading and Writing Together: New Perspective for The Classroom. ChristopherGordon Publisher, Inc. Norword.

Syafe'i, Imam. 1994. Pengajaran Bahasa Indonesia di SD Berdasarkan Kurikulum 1994 dalam Sekolah Dasar: Kajian Teori dan Praktik Pendidikan. Thn. 3 No. 2 November 1994. hlm. 136.

Tompkins, Gaile. 1994. Teaching Writing: Balancing Process and Product. Macmillan College Publishing Company, Inc.

Tompkins, G.E, and Hoskisson, K. 1991. Language Art: Contents and Teaching Strategies. New York: McMillan College Publishing Company. Inc.

Waluyo, Herman J. 2001. Drama: Teori dan Pengajarannya. Yogyakarta: PT Hanindita Graha.

Zuchdi, Darmiyati. 1997. Pembelajaran Menulis dengan Pendekatan Proses. Makalah disajikan dan dibahas pada Senat Fakultas Pendidikan Bahasa dan Seni IKIP Yogyakarta, Yogyakarta, 15 November. 